\title{
Contribution of Agroforestry to Farmers Wellbeing in Forest Enclave, Edo State, Nigeria
}

\section{${ }^{1}$ OJEDOKUN, CA; ${ }^{*}$ UGEGE, BH; ${ }^{1}$ KOLADE, RI; TUNDE-FRANCIS, AA; ${ }^{1}$ ODEDIRAN, FA}

\author{
${ }^{1}$ Forestry Research Institute of Nigeria, P.M.B 5040, Jericho hills, Ibadan, Nigeria \\ ${ }^{2}$ Federal College of Forestry Jericho Ibadan, Nigeria \\ *Corresponding AuthorEmail: bukolasfavour@yahoo.com
}

\begin{abstract}
Agroforestry has recently been experiencing a surge in interest as a cost-effective means to enhance food security and well-being. Thus there is a need to assess its contribution of to farmer's wellbeing. Primary data needed for the study were collected through the administration of questionnaires to agroforestry farmers. Purposive random sampling technique was used to select three forest enclaves in Edo state. A simple random sampling technic was used in the selection of respondents and a total number of 120 copies of questionnaires were administered. Data were analyzed using descriptive statistics such as frequency counts and percentages and inferential statistics such as Chi-square, Pearson Product Moment correlations (PPMC). The study revealed that the mean age of the farmers in the area was 45.6years. Majorities (85.8\%) were male and $78.3 \%$ were married. with $54.2 \%$ having household size of between $4-6$ persons. Majority $(84.2 \%)$ had formal education. Also, $65.8 \%$ engage in agroforestry farming as their primary occupation. The results showed that there was positive and significant relationship between farmers' involvement in agroforestry and their economic wellbeing $\left(\chi^{2}=76.27, \mathrm{P} \leq 0.001\right)$, material wellbeing $\left(\chi^{2}=93.77, \mathrm{P} \leq\right.$ $0.001)$, social wellbeing $\left(\chi^{2}=73.00, \mathrm{P} \leq 0.001\right)$ and psychological wellbeing $\left(\chi^{2}=132.63, \mathrm{P} \leq 0.001\right)$, respectively. It is therefore recommended that farmers should be encouraged to increase their farm holding and also organized themselves into association for them to have access to mechanized equipment.
\end{abstract}

DOI: $\underline{\text { https://dx.doi.org/10.4314/jasem.v24i8.9 }}$

Copyright: Copyright (C) 2020 Ojedokun et al. This is an open access article distributed under the Creative Commons Attribution License (CCL), which permits unrestricted use, distribution, and reproduction in any medium, provided the original work is properly cited.

Dates: Received: 30 May 2020; Revised: 03 July 2020; Accepted: 05 August 2020

Keyword: Contribution, Agroforestry, Wellbeing, Farmers

In Nigeria, there are several sectors that contribute to the total output of the economy. They are grouped into four major sectors, namely agricultural, manufacturing, oil/petroleum and services. The agricultural sector which is our focus is disaggregated into crop production, livestock, forestry and fishing. This sector is particularly important in terms of employment generation and its contribution to the Gross Domestic Product (GDP). In the year 2015, agriculture expansion accelerated to 4.7 percent, crop production was the main drive with a growth share of 82.57 percent (CBN, 2015). Although agriculture no longer serves as the leading contributor to Nigeria's Gross National Product (GNP) or the primary foreign exchange earnings, it is still the dominant economic activity in terms of employment; as this contributes about $46 \%$ share of GDP to the economy. Over the years, the sector has witnessed tremendous decline in its contribution to national development. This is evident in the high incidence of poverty among rural populace. The reasons for this widespread poverty in Sub Saharan Africa include destruction of the natural forest, leading to environmental degradation and reduced productivity. Besides, small farmers usually farm on degraded lands with complex and diverse farming systems (Owese, et.al 2009). In light of recurring food shortages, projected climate change, and rising prices of fossil fuel-based agricultural inputs, agroforestry has recently experienced a surge in interest from the research and development communities, as a cost-effective means to enhance food security, while at the same time contributing to climate change adaptation and mitigation. Agroforestry is the cultivation of tree species with arable crops and or animal productions. It has shown to provide a number of benefits to farmers. For instance, it can enhance soil fertility in many situations and improve farm household resilience through provision of additional products for sale or home consumption (Thangataa and Hildebrand, 2012). Agroforestry can be defined as the strategies that introduce indigenous and exotic trees into cropping systems and impact on livelihoods of small-holder farmers in Sub-Saharan Africa (Kwesiga et al., 2003). It is also an integrated approach of combining trees/shrubs with crops and or livestock. It is a 
common practice in most developing countries. The insight that trees on farms provide livelihood benefits is not new, and diversity-based approaches to agricultural adaptation to climate variability have been adopted by many farmers (Nguyen and Hoang, 2013). It has also experienced a recent increase in adoption by farmers in many parts of Africa as demonstrated by (Garrity et al., 2010). In Nigeria, despite an increase in the Human Development Index from 0.43 in the year 2010 to about 0.70 in the year 2014, the wellbeing level is still very low (Human Development Report, 2014). Considering the fact that agroforestry is being considered as one of the means to ameliorate the effect of climate change and also serve as a means of support to livelihood. it is pertinent to document those factors that determine the wellbeing of agroforestry farmers as an entity, and also to find out if agroforestry practices actually have effect on their wellbeing. Farmers' wellbeing is worth considering; it is a contributing factor to productivity and serves as motivation. Wellbeing is a positive physical, social and mental state; it is not just the absence of pain, discomfort and incapacity. It entails not only from the action of individuals, but from a host of collective good relationships with other people that can achieve important personal goals and participate in society, it is enhanced by supportive personal relationships, involvement in empowered communities, good health, financial security, rewarding employment and a healthy and attractive environment (UK Govt, 2006).Well-being should not be confused with the concept of standard of living, which usually is based primarily on income (GDP per capital). Instead, quality-of-life indicators which include physical and mental health, education, recreation and leisure time, availability of environmental services and social belonging (Anheier and Stares 2002; Fleurbaey 2009; Michaelson et al. 2009). Wellbeing is difficult to define but much more difficult to measure, but recently due to the interest that arouse among social researchers, wellbeing has taken on a multidimensional freedom view to the extent of having several approaches to its measurement. There are four major indicators considered for wellbeing this includes economic, social, material and psychological. Therefore, this study seeks to investigate the contribution of agroforestry to farmer's wellbeing.

\section{MATERIALS AND METHODS}

Study Area: The Study was carried out in Edo State Nigeria. Edo is located in the heart of the tropical rain forest and lies between longitude $5.15^{\circ} \mathrm{E}$ and $6^{\circ} 45^{\prime \prime} \mathrm{E}$ of the Greenwich meridian line and latitude $5^{\circ} 45$ and $7^{\circ} 30^{\prime \prime} \mathrm{N}$ of the Equator. It has a total land area of $19,281.93$ square kilometers. Politically, the state is divided into eighteen (18) local government areas. Edo state is a low-lying area except in the northern part where it is characterized by rolling hills rising to a peak of about 572 metres. It has a tropical climate with two major seasons - the wet and dry seasons. Vegetation in deciduous within the lowland rain forest belt of the south and forest savannah in the north. There are abundant natural resources in the state. Virtually all species of hardwood can be found. Such as Iroko, Obeche, Mahogany etc. The state produces a significant proportion of the country's rubber and crepe (Omofonmwan, 2007).

Data Collection: Primary data needed for the study were collected using a multi-stage sampling technique. The first stage was obtained using a purposive random sampling method by selecting six (6) forest reserves; this selection was based on involvement of farmers in agroforestry practices. In the second stage, three forest enclaves were selected based on the appreciable number of agroforestry farmers in the enclaves. These enclaves are Sakponba, Ubiaja and Agbede using 50\%, $33 \%$ and $17 \%$ respectively; this percentage was based on the population of the enclave dwellers in each of the enclaves. A total of 120 respondents were obtained.

Data Analysis: Data for the study was obtained through the use of structured interview schedule to elicit information from the respondents. The interview schedule was both open and close ended questions.Data collected were analyzed using descriptive statistic such as frequency, table, percentages, bar charts and inferential statistic

\section{RESULTS AND DISCUSSION}

Table1 shows that most of the Agroforestry farmers $(50.8 \%)$ are within the ages $31-50$. This implies that the farmers were in their active ages. This correlates with the finding of (Adeola and Adetunbi, 2015) that active age is likely to make them more responsive to the adoption of innovations. The gender distribution shows that the majority $85.8 \%$ of the respondents were male; this implies that agroforestry farming in the area is mostly dominated by male. This study is in line with the findings of (Rocheleau and Edmunds, 1997) that reported that tree planting and felling have been primarily dominated by male while women have enjoyed use and access rights to fodder, fuelwood, fiber, fruits and mulch.

The table further reveals that $78.3 \%$ were married; this implies that agroforestry farming in the area was dominated by married farmers. This is an indication that agroforestry contributes to their income. The results further reveal that $32.5 \%$ had both secondary education and tertiary education, respectively. 
Table 1 Socio-economic characteristics of the respondents

\begin{tabular}{|c|c|c|}
\hline & Frequency & Percent (\%) \\
\hline \multicolumn{3}{|l|}{ Age } \\
\hline Less than 30 & 15 & 12.5 \\
\hline $31-40$ & 37 & 30.8 \\
\hline $41-50$ & 24 & 20.0 \\
\hline $51-60$ & 26 & 21.7 \\
\hline $61 \&$ above & 18 & 15.0 \\
\hline Total & 120 & 100.0 \\
\hline \multicolumn{3}{|l|}{ Marital Status } \\
\hline Single & 16 & 13.3 \\
\hline Married & 94 & 78.3 \\
\hline Divorced & 5 & 4.2 \\
\hline Widowed & 5 & 4.2 \\
\hline Total & 120 & 100.0 \\
\hline \multicolumn{3}{|l|}{ Religion } \\
\hline Christianity & 100 & 83.3 \\
\hline Islam & 18 & 15.0 \\
\hline Traditional & 2 & 1.7 \\
\hline Total & 120 & 100.0 \\
\hline \multicolumn{3}{|l|}{ Educational Status } \\
\hline No Formal Education & 8 & 6.7 \\
\hline Informal education & 11 & 9.2 \\
\hline Primary education & 39 & 32.5 \\
\hline Secondary education & 39 & 32.5 \\
\hline Tertiary & 23 & 19.2 \\
\hline Total & 120 & 100.0 \\
\hline \multicolumn{3}{|l|}{ Primary Occupation } \\
\hline Agroforestry farmer & 79 & 65.8 \\
\hline Artisan & 2 & 1.7 \\
\hline Business & 2 & 1.7 \\
\hline Civil servant & 18 & 15.0 \\
\hline Extension worker & 1 & 0.8 \\
\hline Fishing & 1 & 0.8 \\
\hline Pensioner & 3 & 2.5 \\
\hline Teacher & 6 & 5.0 \\
\hline Technician & 2 & 1.7 \\
\hline Trading & 6 & 5.0 \\
\hline Total & 120 & 100.0 \\
\hline \multicolumn{3}{|l|}{ Farm size (hectares) } \\
\hline$<4.98$ & 48 & 40.0 \\
\hline $7.41-9.88$ & 41 & 34.2 \\
\hline $12.35-14.82$ & 23 & 19.2 \\
\hline$>17.29$ & 8 & 6.7 \\
\hline Total & 120 & 100 \\
\hline \multicolumn{3}{|l|}{$\begin{array}{l}\text { Reason for } \\
\text { agroforestry }\end{array}$} \\
\hline Relaxation & 1 & 0.8 \\
\hline Source of food & 47 & 39.2 \\
\hline Main source of income & 72 & 60.0 \\
\hline Total & 120 & 100.0 \\
\hline
\end{tabular}

This shows that the majority of the agroforestry farmers in the area are educated this is contrary to the apriority expectation that majority of the farmers are illiterate. The results further reveal that $65.8 \%$ of the respondents had agroforestry farming as primaryoccupation. $60 \%$ of the respondents involved in agro forestry because it serves as a source of income.

Economic well-being of farmers: Table 2 shows the distribution of respondents by economic well-being, the results reveals that the majority $(64.2 \%)$ of the respondents indicated that they were able to eat three square meals per day, $35 \%$ were able to eat two meals per day while $8 \%$ indicated they can only afford just a meal.

Table 2: Distribution of respondents by Economic well being

\begin{tabular}{lll}
\hline & Frequency & Percent \\
\hline Problem satisfying food need & & \\
1 Meal/day & 1 & 0.8 \\
2 Meals/day & 42 & 35.0 \\
3 Meals/day & 77 & 64.2 \\
Total & 120 & 100.0 \\
Problem paying school fees & & \\
Not at all & 31 & 25.8 \\
Twice & 52 & 43.3 \\
At once & 30 & 25.0 \\
Total & 113 & 94.2 \\
System & 7 & 5.8 \\
Total & 120 & 100.0 \\
Problem paying house rent & & \\
Thrice or more & 22 & 18.3 \\
Twice & 42 & 35.0 \\
At once & 15 & 12.5 \\
None & 41 & 34.2 \\
Total & 120 & 100.0 \\
Problem paying utility bills & & \\
Not at all & 33 & 27.5 \\
Occasionally & 56 & 46.7 \\
Regularly & 30 & 25.0 \\
Total & 119 & 99.2 \\
System & 1 & 0.8 \\
Total & 120 & 100.0 \\
\hline &
\end{tabular}

This may be due to the fact that respondents practice agroforestry as a source of food. The result reveals that $43.3 \%$ could afford to pay their children' school fees by splitting the payment twice in a term while $25 \%$ could afford to pay it once. Furthermore, the $35 \%$ pay their house rent in two instalments while $12.5 \%$ could afford to pay once. $46.7 \%$ pays their utility bills occasionally while $25 \%$ could afford to pay bills regularly.

Distribution of respondents by Material wellbeing indicators: Table 3 reveals that $64.2 \%$ sometimes have access to basic infrastructure while $15 \%$ of the respondents always have access, this could be that most of their family resides in town where access to those things are on ground but not necessarily accessible and that some also resides permanently in the enclave. $48.3 \%$ while $21.7 \%$ always have access; the reason is not far from the reason that most enclaves in Nigeria are located in remote rural area where basic infrastructure is a nightmare.

Social wellbeing indicators of farmers: Table 4 reveals that most (49.2\%) of the respondents lived in mud built houses while $7.5 \%$ stayed in a flat. This may be accounted for by the civil servant who engaged in agroforestry. The study also reveals that $\operatorname{most}(63.3 \%)$ of the respondents own their buildings with $55.8 \%$ 
using pit latrines ,84.2\% using their backyard for waste disposal. $54.2 \%$ of the respondents use kerosene as a source of energy.

Table 3: Material well-being indicators of farmers

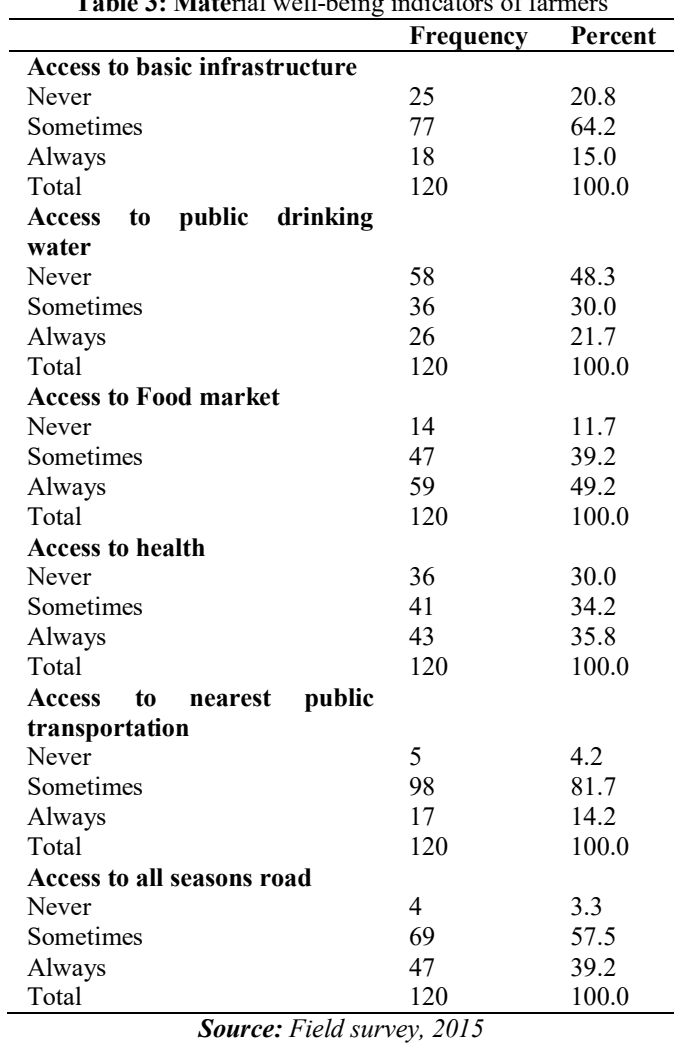

Distribution of respondents by Psychological wellbeing : Table 5 shows the distribution of respondents by psychological wellbeing, $74.2 \%$ indicated that they have fairly achieved their purpose in life The result further reveals their personal growth with $7.5 \%$ indicated that it is worse, $55.8 \%$ indicated that they are the same while $35 \%$ believes they are better. Environmental situation reveals 22.5\% indicated that their environment is not conducive, $63.3 \%$ indicated it is fairly conducive and $12.5 \%$ as conducive. Meanwhile the result shows that selfacceptance indicated $9.2 \%$ as not applicable, services to others indicated by $70.8 \%$ and $18.3 \%$ does to enhance their income.

Relationship between the reason for farmers' involvement in agroforestry practices and wellbeing of the respondents: The table 6 shows the Chi-square results for the relationship between the reasons for farmers' involvement in agroforestry practices and their wellbeing. The results shows that there was positive and significant relationship between farmers' involvement in agroforestry and; economic wellbeing $\left(\chi^{2}=76.27, \mathrm{P} \leq 0.001\right)$, material wellbeing $\left(\chi^{2}=93.77\right.$, $\mathrm{P} \leq 0.001)$, social wellbeing $\left(\chi^{2}=73.00, \mathrm{P} \leq 0.001\right)$ and psychological wellbeing $\left(\chi^{2}=132.63, \mathrm{P} \leq 0.001\right)$, respectively.

Table 4 Distribution of respondents by Social wellbeing indicators

\begin{tabular}{|c|c|c|}
\hline & Frequency & Percent \\
\hline \multicolumn{3}{|l|}{ Problem satisfying food need } \\
\hline One room apartment & 26 & 21.7 \\
\hline Mud built bungalow & 59 & 49.2 \\
\hline Block built bungalow & 26 & 21.7 \\
\hline Flat & 9 & 7.5 \\
\hline Total & 120 & 100.0 \\
\hline \multicolumn{3}{|l|}{ Ownership of house } \\
\hline Tenant & 76 & 63.3 \\
\hline Landlord & 44 & 36.7 \\
\hline Total & 120 & 100.0 \\
\hline \multicolumn{3}{|l|}{ Source of drinking water } \\
\hline Stream & 36 & 30.0 \\
\hline Well & 50 & 41.7 \\
\hline Pipe borme & 6 & 5.0 \\
\hline Pump & 3 & 2.5 \\
\hline Borehole & 25 & 20.8 \\
\hline Total & 120 & 100.0 \\
\hline \multicolumn{3}{|l|}{ Type of toilet facility } \\
\hline None & 14 & 11.7 \\
\hline Bucket & 21 & 17.5 \\
\hline Pit latrine & 67 & 55.8 \\
\hline Water system & 18 & 15.0 \\
\hline Total & 120 & 100.0 \\
\hline \multicolumn{3}{|l|}{ Type of waste disposal } \\
\hline Backyard & 101 & 84.2 \\
\hline Public sewage & 1 & 0.8 \\
\hline Dust bin & 17 & 14.2 \\
\hline Total & 119 & 99.2 \\
\hline System & 1 & 0.8 \\
\hline Total & 120 & 100.0 \\
\hline \multicolumn{3}{|l|}{ Type of drainage } \\
\hline Open & 105 & 87.5 \\
\hline Closed & 11 & 9.2 \\
\hline Total & 116 & 96.7 \\
\hline System & 4 & 3.3 \\
\hline Total & 120 & 100.0 \\
\hline \multicolumn{3}{|l|}{ Source of power } \\
\hline Kerosene lantern & 65 & 54.2 \\
\hline Generator & 20 & 16.7 \\
\hline Electricity & 35 & 29.2 \\
\hline Total & 120 & 100.0 \\
\hline
\end{tabular}

Source: Field survey, 2015

The positive and significant relationship between reason for involvement and wellbeing shows that involvement in agroforestry enhances farmers' wellbeing; this agree with Idumah et al(2014) that agroforestry practices improve crop yield and farmers' income from fuel wood and hence higher income which will aid their wellbeing.

Conclusion: Based on the evidence presented by this study, the wellbeing of agroforestry farmers when compared with the country HDI is better and premised largely on their social, economic, material and psychological states. It is therefore recommended that 
Farmers should be encouraged to increase their farm holding and organize themselves into association to access to modern equipment for farming and also farmers should be given the opportunity of gaining access to good transportation to enhance their production and wellbeing.

Table 5: Psychological well-being of farmers

\begin{tabular}{|c|c|c|}
\hline & Frequency & Percent \\
\hline \multicolumn{3}{|l|}{ Purpose in life } \\
\hline Not achieved & 22 & 18.3 \\
\hline Fairly achieved & 89 & 74.2 \\
\hline Achieved & 7 & 5.8 \\
\hline Total & 118 & 98.3 \\
\hline System & 2 & 1.7 \\
\hline Total & 120 & 100.0 \\
\hline \multicolumn{3}{|c|}{ Environmental situation } \\
\hline Not conducive & 27 & 22.5 \\
\hline Fairly conducive & 76 & 63.3 \\
\hline Conducive & 15 & 12.5 \\
\hline Total & 118 & 98.3 \\
\hline System & 2 & 1.7 \\
\hline Total & 120 & 100.0 \\
\hline \multicolumn{3}{|l|}{ Self-acceptance } \\
\hline Unsatisfactory & 30 & 25.0 \\
\hline Fairly satisfactory & 69 & 57.5 \\
\hline Satisfactory & 21 & 17.5 \\
\hline Total & 120 & 100.0 \\
\hline \multicolumn{3}{|c|}{ Purpose of relation with others } \\
\hline Not applicable & 11 & 9.2 \\
\hline Service to others & 85 & 70.8 \\
\hline Income enhancement & 22 & 18.3 \\
\hline Total & 118 & 98.3 \\
\hline System & 2 & 1.7 \\
\hline Total & 120 & 100.0 \\
\hline \multicolumn{3}{|c|}{ Purpose of relation with others } \\
\hline Not applicable & 11 & 9.2 \\
\hline Service to others & 85 & 70.8 \\
\hline Income enhancement & 22 & 18.3 \\
\hline Total & 118 & 98.3 \\
\hline System & 2 & 1.7 \\
\hline Total & 120 & 100.0 \\
\hline
\end{tabular}

Table 6. Results of Chi-square the relationship between the reason for farmers' involvement in agroforestry practices and wellbeing of

\begin{tabular}{lllll}
\multicolumn{5}{c}{ the respondents } \\
\hline Variables & $\chi^{2}$ & Df & P-value & Decision \\
\hline Economic well being & 76.27 & 7 & 0.000 & $\mathrm{~S}$ \\
$\begin{array}{l}\text { Material well being } \\
\text { Social wellbeing }\end{array}$ & 93.77 & 10 & 0.000 & $\mathrm{~S}$ \\
$\begin{array}{l}\text { Psychological well } \\
\text { being }\end{array}$ & 132.63 & 19 & 0.000 & $\mathrm{~S}$ \\
\end{tabular}

Source: Field survey, 2015; Note: S = Significant

\section{REFERENCES}

Adeola, RG; Adetunbi, SI (2015) Farmers' Perception of Sustainable Agriculture in South- Western Nigeria: Implications for Rural Economy Inter. J. Appl. Agric. Apicultural Res. 11(1\&2): 86-92.

Anheier, H; Sally, S (2002). "Introducing the Global Civil Society Index." In Global Civil Society Yearbook 2002, edited by Marlies Glasius, Mary Kaldor, and Helmut K.Anheier (241- 54). Oxford, UK: Oxford University Press.

Fleurbaey, M. (2009). "Beyond GDP: The Quest for a Measure of Social Welfare." J. Econ. Lit. 47(4): 1029-75.

Garrity, DP; Akinnifesi, FK; Ajayi, OC, Weldesemayat, SG; Mowo, JG, Kalinganire, A. Larwanou, M. Bayala, J. (2010) Evergreen Agriculture: A Robust Approach to Sustainable. Food Security in Africa. Food Sec. 2:197-214.

Idumah, FO; Owombo, PT; Ighodaro, UB (2014). Economics of Yam Production under Agroforestry System in Saponba Forest Area, Edo State, Nigeria. Inter. J. Agric. Fores. 4(6): 440-445

Kwesiga F, Akinnifesi FK, Mafongoya PL, McDermott MH, and Agumya A (2003) Agroforestry Research and Development in Southern Africa during the 1990s: Review and Challenges Ahead. Agroforestry Systems 59: 173-186

Michaelson, Juliet, Saamah Abdallah, Nicola Steuer, Sam Thompson, and Nic Marks. (2009). "National Accounts of Well-Being: Bringing Real Wealth onto the Balance Sheet." London: New Economics Foundation.

Nguyen Q, Hoang M.H, O־born I; Noordwijk, MV (2013): Multipurpose Agroforestry as a Climate Change Resiliency Option for Farmers: An Example of Local Adaptation in Vietnam. Climatic Change 117:241-257. 14.

Omofonmwan, S.I (2007), Problems and Prospects of Rice Production in the Central District of Edo State, Nigeria. J. Human Ecol. 22(2):123-128

Owese, T.O. Odebode, A.V. \& Amadi, J.O (2009). Prospects of Agroforestry as a Veritable "Turning the tide on Farm Productivity in Africa: An Agroforestry Solution". July 8, 2009.Retrieved 2 April 2014. Principles and Practices. The Netherlands. Elsevier Science Publishing Company, Pp. 5-16

Thangataa P.H. and Hildebrand P.E (2012): Carbon Stock and Sequestration Potential of Agroforestry Systems in Smallholder Agro-Ecosystems of SubSaharan Africa: Mechanisms for 'Reducing Emissions from Deforestation and Forest Degradation' (REDD+). Agric. Ecosyst. Environ. 158:172-183. 13.

Rocheleau D, Edmunds D (1997) Women, Men and Trees: Gender, Power and Property in Forest and Agrarian Landscapes. World Dev 25(8):1351-1371 